\title{
Date of Sowing and Row Spacing for Improving Growth Attributes of Baby Corn
}

\author{
Lipika Talukdar*, Pradip Chandra Bora, Khagen Kurmi and Sontara Kalita
}

Assam Agricultural University, Jorhat-13, India

*Corresponding author

\section{A B S T R A C T}

\section{Keywords}

Baby corn, Growth attributes, Sowing, Spacing, Leaf area index, Tasseling, yield

\section{Article Info}

Accepted:

14 June 2020

Available Online:

10 July 2020
A field experiment was carried out at the Instrutional-Cum-Research farm. Assam Agricultural University, Jorhat in the year of 2017-18, during rabi season. The treatment consisted of two different factors, viz., four dates of sowing $31^{\text {st }}$ October $\left(D_{1}\right), 10^{\text {th }}$ November $\left(D_{2}\right), 20^{\text {th }}$ November $\left(D_{3}\right)$ and $30^{\text {th }}$ November $\left(D_{4}\right)$ and three row spacing $60 \mathrm{~cm}$ x $20 \mathrm{~cm}\left(\mathrm{~S}_{1}\right), 45 \mathrm{~cm}$ x $20 \mathrm{~cm}\left(\mathrm{~S}_{2}\right)$ and $30 \mathrm{~cm}$ x $20 \mathrm{~cm}\left(\mathrm{~S}_{3}\right)$. Experimental findings revealed that almost all the growth attributes such as plant height, number of leaves per plant, leaf area index, dry matter accumulation per plant, crop growth rate and baby corn yield were significantly influenced by different dates of sowing. In most of cases early sowing on $31^{\text {st }}$ October and $10^{\text {th }}$ November were statistically at par and shown their superiority over late sowing on $20^{\text {th }}$ November and $30^{\text {th }}$ November sown crop. The dates of sowing showed significant difference on harvest duration of baby corn. The highest harvest duration was found in $31^{\text {st }}$ October sown crop which was statistically at par with $10^{\text {th }}$ November sown crop. Results showed that at 50,75 DAS and and at harvest spacing $30 \mathrm{~cm} \times 20 \mathrm{~cm}$ recorded significantly higher plant height and crop growth rate over those of $45 \mathrm{~cm} \times 20$ $\mathrm{cm}$ and $60 \mathrm{~cm} \times 20 \mathrm{~cm}$ spacing. The maximum number of leaves plant ${ }^{-1}$ and maximum baby corn yield were recorded under the spacing of $45 \mathrm{~cm}$ x $20 \mathrm{~cm}\left(\mathrm{~S}_{2}\right)$ which were significantly higher than other. The highest leaf area index and harvest duration was recorded under the spacing of $60 \mathrm{~cm}$ x $20 \mathrm{~cm}\left(\mathrm{~S}_{1}\right)$ which was significantly higher than those for all other row spacing at 60 DAS and at tasseling.

\section{Introduction}

Maize (Zea mays L.) is the world's third leading cereal crop after wheat and rice. In the world it accounts for 8 and 25 per cent of the area and production of cereals, respectively. It occupies an important position in the world economy and trade as a food, feed and industrial grain crop. Maize is one of the most versatile crop and can be grown in diverse environmental conditions and has diversified uses as human food and animal feed. It has got immense potential and is therefore called as 'miracle crop'. For diversification and value addition of maize as well as the growth of the food processing industry, many new vegetables have been evolved. One among them is baby corn (Muthukumar et al., 2005). Das et al., (2009) reported that $100 \mathrm{~g}$ of baby corn contained $0.2 \mathrm{~g}$ fat, $1.9 \mathrm{~g}$ protein, $8.2 \mathrm{mg}$ 
carbohydrate, $0.06 \mathrm{~g}$ ash, $28.0 \mathrm{mg}$ calcium, $86.0 \mathrm{mg}$ phosphorus, and $11.0 \mathrm{mg}$ of ascorbic acid. It is rich in phosphorus content $(86 \mathrm{mg}$ Phosphorus per $100 \mathrm{~g}$ edible portion in comparison to 21 to $57 \mathrm{mg}$ in other commonly used vegetables). It is a low calorie vegetable having higher fiber content without cholesterol.

Besides nutritive advantage, it is also free from residual effect of pesticides as it is harvested within a week of tassel emergence and the young cob is wrapped up tightly with husk and well protected from insects and pests (Kumar et al., 2004).

With the fast change in standard of living and increasing concern for health, people are looking for quality food in place of bulky items. Baby corn has prime place as a safe and quality vegetable. However, the location specific technologies for the crop are not available. Therefore agro-techniques to achieve higher production are the need of the day. Sowing time is an important factor influencing the performance of the crop since it is important for better utilization of available moisture and nutrients supplied to the crop. Planting date was reported to affect the growth of baby corn significantly by Khan et al., 2002. One of the most important factors contributing to yield gap is sowing of crop on appropriate time. Sowing time is an important factor influencing the performance of the crop by providing the optimal environmental condition for growth as it is important for better utilization of available moisture and nutrients by the crop. Similarly, optimum plant geometry is another important factor for efficient utilization of resources and also harvesting as much as solar radiation and in turn better photosynthesis leading to higher production. Maximum yield can be expected only when plant spacing allows individual plant to achieve their maximum inherent potential. Though the spacing requirements of grain and fodder maize are well defined, but such information is meager in case of baby corn. Therefore, it is essential to standardize the date of sowing and row spacing of baby corn.

\section{Materials and Methods}

The field experiment was carried out at the Instrutional-cum-Research Farm. Assam Agricultural University, Jorhat-13 during the rabi of 2017-18. The site is situated at $26^{\circ} 47^{\prime}$ $\mathrm{N}$ latitude and $94^{\circ} 12^{\prime} \mathrm{E}$ longitude with an altitude of 86.56 meter above the mean sea level. Jorhat is a sub-tropical station with hot and humid summers and cold and dry winters. The normal monsoon rain starts from the months of June and continues upto September with pre-monsoon shower from mid March to April. The experiment was laid out in splitplot design and replicated thrice. the treatment consist of four dates of sowing $31^{\text {st }}$ October $\left(D_{1}\right), 10^{\text {th }}$ November $\left(D_{2}\right), 20^{\text {th }}$ November $\left(D_{3}\right)$ and $30^{\text {th }}$ November $\left(D_{4}\right)$ and three row spacing $60 \mathrm{~cm} \times 20 \mathrm{~cm}\left(\mathrm{~S}_{1}\right), 45 \mathrm{~cm} \times 20 \mathrm{~cm}$ $\left(\mathrm{S}_{2}\right)$ and $30 \mathrm{~cm} \times 20 \mathrm{~cm}\left(\mathrm{~S}_{3}\right)$. The baby corn Cv. G-5414 was sown with application of recommended $\mathrm{N}: \mathrm{P}_{2} \mathrm{O}: \mathrm{K}_{2} \mathrm{O}$ (90:60:60 kg ha ${ }^{-1}$ ) and farm yard manure (FYM) @ 2.5t ha ${ }^{-1}$. At the time soil of last ploughing FYM was applied and mixed thoroughly with soil. Full dose of phosphatic and potassic fertilizers and half dose of nitrogenous fertilizers were applied as uniformly before sowing. The rest half of the nitrogenous fertilizer was applied as top dressing at the time of earthing up (30DAS). Harvesting of baby corn was done at 2-3 days of silking.

\section{Results and Discussion}

\section{Effect of date of sowing on growth attributes of baby corn}

Data presented in Tables 1 and 2 and Fig. 1 revealed that among various growths 
attributes viz., plant height, number of leaves plant $^{-1}$, leaf area index, dry matter accumulation plant $^{-1}$ and crop growth rate recorded at periodical interval were significantly influenced under different dates of sowing. The crop sown either on $\mathrm{D}_{1}$ or $\mathrm{D}_{2}$ was equally good in improving the values of various growth parameters studied over late sown crop. Subsequent delayed in sowing numerically reduced plant height, number of leaves plant $^{-1}$, leaf area index, dry matter accumulation plant $^{-1}$ and crop growth rate compared to earlier sowing. Thus, baby corn sown either on $31^{\text {st }}$ October or $10^{\text {th }}$ November was found significantly superior in respect of growth atriburtes to delay sowing on $30^{\text {th }}$
November. This was probably due to early sown crop may enjoy favourable climatic conditions in term of temperature and other climatic parameter during various crop growth stages, which reflected into better growth. This was also attributed to early germination and initial vigorous growth of plant in early sowing compared to late sowing. The highest baby corn yield $(21.20 \mathrm{q}$ $\mathrm{ha}^{-1}$ ) (Table 3) was recorded by the $31^{\text {st }}$ October $\left(D_{1}\right)$ sown crop which was statistically at par with that of $10^{\text {th }}$ November $\left(19.73 \mathrm{q} \mathrm{ha}^{-1}\right)\left(\mathrm{D}_{2}\right)$ sown crop, however, the values were significantly higher than those of $20^{\text {th }}$ November $\left(\mathrm{D}_{3}\right)$ and $30^{\text {th }}$ November $\left(\mathrm{D}_{4}\right)$ sown crop.

Table.1 Effect of dates of sowing and row spacing on plant height $(\mathrm{cm})$ and number of leaves plant $^{-1}$ of baby corn

\begin{tabular}{|c|c|c|c|c|c|c|c|c|}
\hline \multirow[t]{2}{*}{ Treatments } & \multicolumn{4}{|c|}{ Plant height (cm) } & \multicolumn{4}{|c|}{ Number of leaves per plant ${ }^{-}$} \\
\hline & $\begin{array}{c}25 \\
\text { DAS }\end{array}$ & 50 DAS & 75DAS & $\begin{array}{c}\text { At } \\
\text { harvest }\end{array}$ & 25 DAS & 50 DAS & 75 DAS & $\begin{array}{c}\text { At } \\
\text { harvest }\end{array}$ \\
\hline \multicolumn{9}{|c|}{ Dates of sowing } \\
\hline $\begin{array}{l}D_{1}\left(31^{\text {st }}\right. \\
\text { October })\end{array}$ & 25.42 & 57.49 & 131.00 & 182.67 & 8.91 & 9.76 & 12.45 & 11.67 \\
\hline $\begin{array}{l}D_{2}\left(10^{\text {th }}\right. \\
\text { November })\end{array}$ & 25.24 & 54.73 & 126.49 & 179.53 & 9.00 & 10.89 & 13.78 & 12.78 \\
\hline $\begin{array}{l}D_{3}\left(20^{\text {th }}\right. \\
\text { November })\end{array}$ & 24.97 & 42.42 & 96.71 & 149.07 & 7.07 & 8.97 & 11.17 & 10.05 \\
\hline $\begin{array}{l}\mathrm{D}_{4}\left(30^{\text {th }}\right. \\
\text { November })\end{array}$ & 23.86 & 39.78 & 90.35 & 132.11 & 6.78 & 7.79 & 11.03 & 9.25 \\
\hline S.Em. $( \pm)$ & 0.85 & 1.96 & 3.61 & 4.93 & 0.31 & 0.23 & 0.40 & 0.49 \\
\hline C.D (0.05) & NS & 6.77 & 12.49 & 17.06 & 1.06 & 0.81 & 1.39 & 1.71 \\
\hline \multicolumn{9}{|l|}{ Spacing (cm) } \\
\hline$S_{1}(60 \times 20)$ & 24.45 & 42.71 & 100.31 & 147.75 & 7.64 & 8.94 & 12.59 & 11.05 \\
\hline$S_{2}(45 \times 20)$ & 25.33 & 48.96 & 110.99 & 160.63 & 8.77 & 10.66 & 13.43 & 12.02 \\
\hline$S_{3}(30 \times 20)$ & 24.84 & 54.14 & 122.11 & 174.15 & 7.42 & 8.46 & 10.29 & 9.74 \\
\hline S.Em. $( \pm)$ & 0.73 & 1.69 & 3.12 & 4.27 & 0.26 & 0.20 & 0.35 & 0.43 \\
\hline C.D (0.05) & NS & 5.08 & 9.37 & 12.80 & 0.79 & 0.60 & 1.04 & 1.28 \\
\hline \multicolumn{9}{|c|}{ Interaction (D x S) } \\
\hline S.Em.( $( \pm)$ & 1.47 & 3.39 & 6.25 & 8.54 & 0.53 & 0.40 & 0.70 & 0.86 \\
\hline C.D (0.05) & NS* & NS & NS & NS & NS* & NS & NS & NS \\
\hline
\end{tabular}


Table. 2 Effect of dates of sowing and row spacing on leaf area index, dry matter accumulation(g plant $\left.{ }^{-1}\right)$ and Crop growth rate $\left(\mathrm{g} \mathrm{m}^{-2} \mathrm{day}^{-1}\right)$ of baby corn

\begin{tabular}{|c|c|c|c|c|c|c|c|c|c|c|c|}
\hline \multirow[t]{2}{*}{ Treatments } & \multicolumn{3}{|c|}{ Leaf area index } & \multicolumn{4}{|c|}{ Dry matter accumulation } & \multicolumn{4}{|c|}{ Crop growth rate } \\
\hline & $\begin{array}{c}30 \\
\text { DAS }\end{array}$ & $\begin{array}{c}\text { 60 } \\
\text { DAS }\end{array}$ & $\begin{array}{c}\text { At } \\
\text { tasseling }\end{array}$ & 25DAS & 50DAS & $\begin{array}{c}75 \\
\text { DAS }\end{array}$ & $\begin{array}{c}\text { At } \\
\text { harvest }\end{array}$ & 25DAS & 50DAS & $\begin{array}{c}75 \\
\text { DAS }\end{array}$ & $\begin{array}{c}\text { At } \\
\text { harvest }\end{array}$ \\
\hline \multicolumn{12}{|c|}{ Dates of sowing } \\
\hline $\begin{array}{l}D_{1}\left(31^{\text {st }}\right. \\
\text { October })\end{array}$ & 2.51 & 5.77 & 6.93 & 9.10 & 53.93 & 79.40 & 93.20 & 4.28 & 21.45 & 12.17 & 6.27 \\
\hline $\begin{array}{l}D_{2}\left(10^{\text {th }}\right. \\
\text { November })\end{array}$ & 2.41 & 5.22 & 6.10 & 9.31 & 50.93 & 72.98 & 85.39 & 4.41 & 19.46 & 10.72 & 5.77 \\
\hline $\begin{array}{l}D_{3}\left(20^{\text {th }}\right. \\
\text { November })\end{array}$ & 2.36 & 4.50 & 5.15 & 8.33 & 43.97 & 65.29 & 75.95 & 3.82 & 16.58 & 9.56 & 5.82 \\
\hline $\begin{array}{l}\mathrm{D}_{4}\left(\mathbf{3 0}^{\text {th }}\right. \\
\text { November })\end{array}$ & 2.32 & 4.46 & 5.00 & 7.57 & 43.58 & 58.28 & 75.83 & 3.46 & 16.61 & 6.97 & 8.49 \\
\hline S.Em. $( \pm)$ & 0.07 & 0.16 & 0.25 & 0.22 & 1.99 & 2.10 & 2.45 & 0.09 & 1.18 & 1.13 & 1.69 \\
\hline C.D (0.05) & NS & 0.57 & 0.87 & 0.78 & 6.87 & 7.27 & 8.48 & 0.30 & 4.08 & NS & NS \\
\hline \multicolumn{12}{|l|}{ Spacing $(\mathbf{c m})$} \\
\hline$S_{1}(60 \times 20)$ & 2.49 & 5.66 & 6.49 & 10.05 & 53.84 & 76.15 & 89.06 & 3.35 & 14.60 & 7.44 & 4.30 \\
\hline$S_{2}(45 \times 20)$ & 2.37 & 4.70 & 5.65 & 8.21 & 48.19 & 68.27 & 82.45 & 3.65 & 17.77 & 8.62 & 6.61 \\
\hline$S_{3}(30 \times 20)$ & 2.34 & 4.60 & 5.25 & 7.47 & 42.28 & 62.53 & 75.81 & 4.98 & 23.20 & 13.50 & 8.85 \\
\hline S.Em. $( \pm)$ & 0.06 & 0.14 & 0.22 & 0.19 & 1.72 & 1.82 & 2.04 & 0.08 & 1.02 & 0.98 & 1.46 \\
\hline C.D $(0.05)$ & NS & 0.43 & 0.65 & 0.58 & 5.16 & 5.46 & 6.13 & 0.23 & 3.06 & 2.94 & NS \\
\hline \multicolumn{12}{|c|}{ Interaction (D x S) } \\
\hline S.Em. $( \pm)$ & 0.12 & 0.28 & 0.44 & 0.39 & 3.44 & 3.64 & 4.09 & 0.15 & 2.04 & 0.70 & 2.92 \\
\hline C.D $(0.05)$ & NS & NS & NS & NS & NS & NS & NS & NS & NS & NS & NS \\
\hline
\end{tabular}

Table.3 Effect of dates of sowing and row spacing on days to different phenological stages and yield baby corn

\begin{tabular}{|c|c|c|c|c|c|c|}
\hline Treatments & $\begin{array}{c}\text { Days to } \\
\text { tasseling }\end{array}$ & $\begin{array}{l}\text { Days to } \\
\text { silking }\end{array}$ & $\begin{array}{l}\text { Days to } 1^{\text {st }} \\
\text { picking }\end{array}$ & $\begin{array}{c}\text { Harvest } \\
\text { duration }\end{array}$ & $\begin{array}{c}\text { Crop } \\
\text { duration }\end{array}$ & $\begin{array}{l}\text { Baby corn } \\
\text { yield }\end{array}$ \\
\hline \multicolumn{7}{|c|}{ Dates of sowing } \\
\hline $\begin{array}{l}D_{1}\left(3^{\text {st }}\right. \\
\text { October })\end{array}$ & 95.56 & 102.33 & 104.56 & 19.00 & 123.56 & 21.20 \\
\hline $\begin{array}{l}D_{2}\left(10^{\text {th }}\right. \\
\text { November })\end{array}$ & 96.54 & 102.44 & 104.67 & 18.22 & 122.89 & 19.73 \\
\hline $\begin{array}{l}D_{3}\left(20^{\text {th }}\right. \\
\text { November })\end{array}$ & 97.11 & 103.38 & 104.89 & 13.89 & 120.44 & 17.10 \\
\hline $\begin{array}{l}D_{4}\left(30^{\text {th }}\right. \\
\text { November })\end{array}$ & 98.67 & 104.11 & 105.89 & 11.33 & 120.89 & 16.30 \\
\hline S.Em. $( \pm)$ & 2.91 & 2.48 & 3.09 & 0.56 & 3.02 & 0.64 \\
\hline C.D (0.05) & NS & NS & NS & 1.95 & NS & 2.21 \\
\hline \multicolumn{7}{|l|}{ Spacing (cm) } \\
\hline$S_{1}(60 \times 20)$ & 96.57 & 101.08 & 104.17 & 17.00 & 121.92 & 18.47 \\
\hline$S_{2}(45 \times 20)$ & 96.92 & 103.17 & 104.83 & 15.50 & 122.92 & 20.79 \\
\hline$S_{3}(30 \times 20)$ & 97.42 & 104.95 & 106.00 & 14.33 & 121.00 & 16.49 \\
\hline S.Em. $( \pm)$ & 2.52 & 2.15 & 2.67 & 0.49 & 2.62 & 0.55 \\
\hline C.D (0.05) & NS & NS & NS & 1.46 & NS & 1.66 \\
\hline \multicolumn{7}{|c|}{ Interaction (D x S) } \\
\hline S.Em. $( \pm)$ & 5.04 & 4.29 & 5.35 & 0.97 & 5.24 & 1.10 \\
\hline C.D (0.05) & NS & NS & NS & NS & NS & NS \\
\hline
\end{tabular}


Fig.1 Effect of Dates of Sowing on Crop Growth Rate $\left(\mathrm{g} \mathrm{m}^{-2} \mathrm{day}^{-1}\right)$

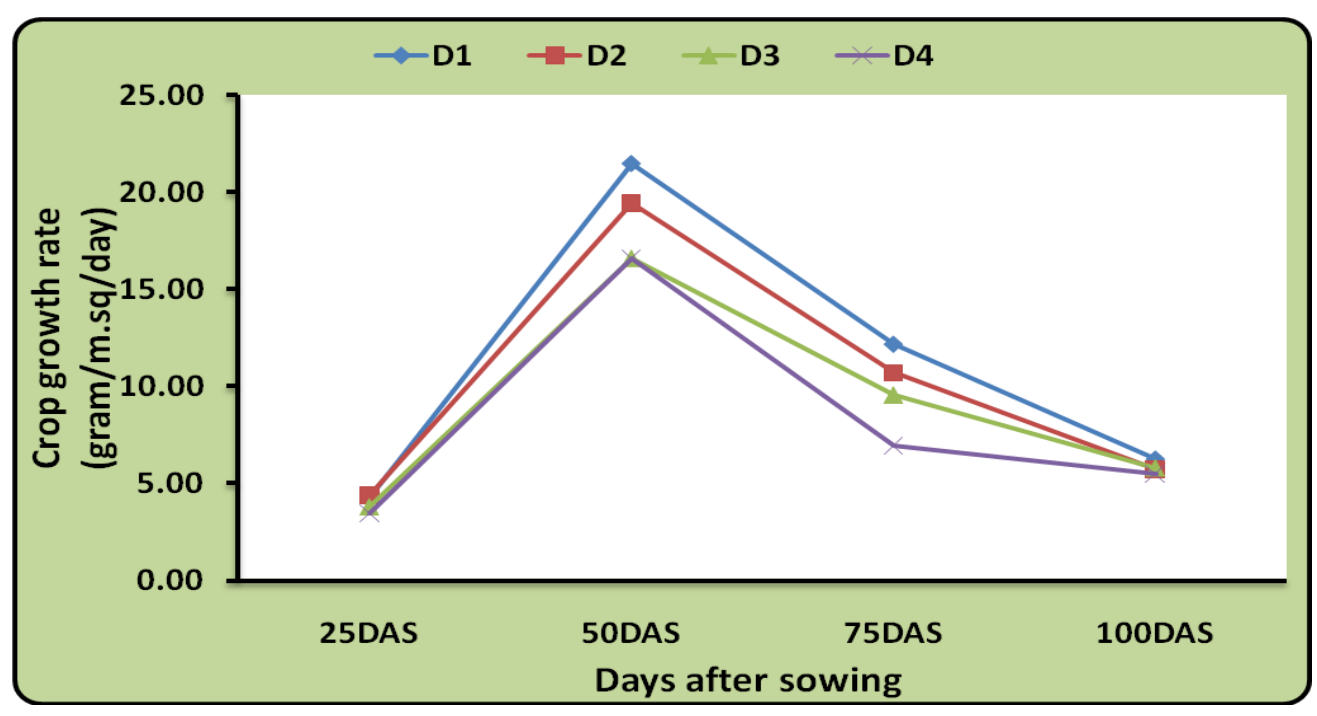

Fig.2 Effect of Row Spacing on Crop Growth Rate $\left(\mathrm{g} \mathrm{m}^{-2}\right.$ day $\left.^{-1}\right)$

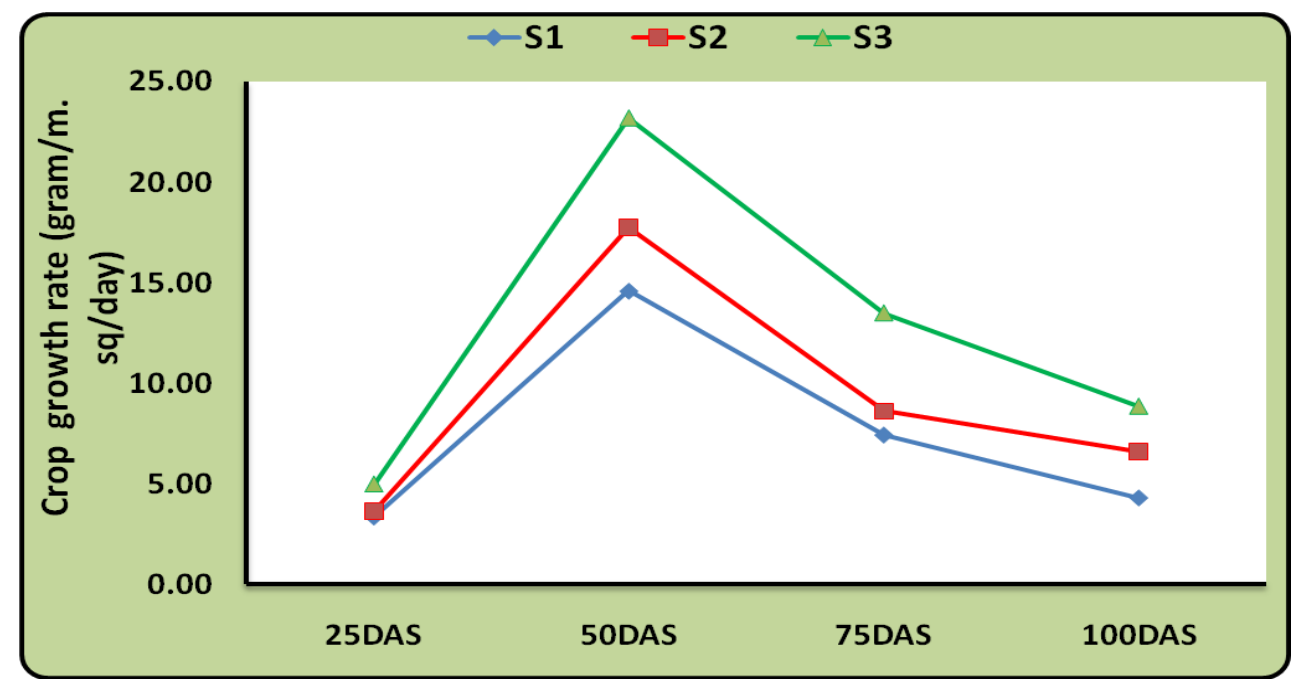

The increase in baby corn yield may be attributed to increase in growth attributing characters. These results land supported to those reported by Rahman et al., (2001) at Hudeiba (Northern Sudan), Song et al., (2008) at china, Rahmani et al., (2010) at Iran and Bairagi et al., (2015) at West Bengal in respect to plant height, number of leaves plant $^{-1}$ and dry matter accumulation. The sowing dates had non- significant effect on days to tasselling, silking, days to $1^{\text {st }}$ picking, and crop duration.(Table 3).These results land supported to those reported by Nandal and Agarwal (1991) and Rahman et al., (2001).

\section{Effect of row spacing on growth attributes of baby corn}

Row spacing due to its multifarious effect on the plant growth influenced the crop yield remarkably. It is clear from the result presented in Table 1 that the different spacing has been found to exert a significant difference on plant height except during 
initial state of growth. The data regarding plant height at 50,75 DAS and at harvest revealed that $30 \mathrm{~cm} \times 20 \mathrm{~cm}$ row spacing recorded significantly higher plant height as compared to others row spacing treatments. The higher plant height in closer spacing might be attributed to increase in competition for sunlight, nutrients, space and water by the plants which coupled with favorable climatic conditions especially temperature might have resulted in maximum plant height. The closely spaced crop has the very little space for their lateral development and there was more vertical expansion of main shoot. The results are in conformity with the findings of Chougule (2003), Kunjir et al., (2007) and Verma et al., (2012).

In case of number of leaves per plant, leaf area index and dry matter accumulation per plant (Tables 1 and 2) reverse trend was observed. Crop sown at wider row spacing either at $60 \mathrm{~cm} \times 20 \mathrm{~cm}$ or $45 \mathrm{~cm} \times 20 \mathrm{~cm}$ apart were equally good but significantly better than close planted crop with regards to almost all the above characters. This might be due to availability of more ground area per plant which received higher growth inputs (sunlight, water and nutrients etc.) with least competition. Larger canopy development, associate with profuse leaf formation might have increased intersection, absorption and utilization of solar energy resulted in formation of higher photosynthesis.

The results were in agreement with those reported by Sukanya et al., (2000) and Thakur and Sharma (2000). On the other hand, crop growth rate increased with increasing levels of plant population.(Table 2) as the maximum and the minimum biomass in unit of area obtained from $S_{3}$ and $S_{1}$, respectively. The increased in CGR with the increasing rate of plant population might be due to more photosynthesis activity and increased number of plants per unit area. Similar results were also reported by Edward et al., (2005) and Sharifi et al., (2014).

The data in table 3 also revealed that days to tasseling, silking and $1^{\text {st }}$ picking as well as crop duration not significantly influenced by different row spacing. Wider row spacing either $60 \mathrm{~cm} \times 20 \mathrm{~cm}$ and $45 \mathrm{~cm} \times 20 \mathrm{~cm}$ were found equally good but better than closer spacing of $30 \mathrm{~m} \times 20 \mathrm{~cm}$. This might be due to sufficient vegetative growth and adequate supply of moisture and nutrients under wider row spacing. The highest baby corn yield was recorded under the spacing of $45 \mathrm{~cm} \times 20 \mathrm{~cm}$ $\left(S_{2}\right)$. Under wider row spacing of $60 \mathrm{~cm} \times 20$ $\mathrm{cm}$, most of the growth attributing characters were at their highest but due of lesser plant population per unit area, it could not compensate the baby corn yield. The increase in baby corn yield under $S_{2}$ is mainly due to increased in growth attributing characters and secondly, it might be due to more number of plants per unit area. These results were in conformity with the findings of Ramachandrappa et al., (2004), Thavaprakash et al., (2005), Kar et al., (2006), Thavaprakaash and Velayudham (2009), Arvadiya et al., (2012), Rathika (2014) and Ghosh et al., (2017).

\section{References}

Arvadiya, L.K.; Raj, V.C.; Patel, T.U and Arvadiya, M.K. (2012). Influence of plant population and weed management on weed flora and productivity of sweet corn. Indian J. Agron. 57(2): 162-167.

Bairagi, S.; Pandit, M. K.; Sidhya, P.; Adhikary, S. and Koundinya, A. V. V. (2015). Impacts of date of planting and crop geometry on growth and yield of baby corn (Zea mays var. rugosa). Journal Crop and Weed. 11(2): 127-131.

Chougule, S. D. (2003). Effect of different plant geometry on sweet corn growth. 
Maharashtra J. Agric. Sci. 34(12): 122125.

Das, S.; Ghosh, G.; Kaleem, M.D. and Bahadur, V. (2009). Effect of different levels of nitrogen and crop geometry on the growth, yield and quality of baby corn (Zea mays L.) cv. 'golden baby'. Acta Hort. 809: 161-166.

Edward, J. T.; Purcell, L. C. and Vories, E. D. (2005). Light interception and yield potential of short-season maize (Zea mays L.) hybrids in the Midsouth. Agron. J. 97(1): 225-234.

Ghosh, M.; Maity, S.K.; Gupta, S.K. and Chowdhury, A.R. (2017). Performance of baby corn under different plant densities and fertility levels in lateritic soils of Eastern India. Intern. J. Pure App. Biosci. 5(3): 696-702.

Kar, P. P.; Barik, K. C.; Mahapatra, P. K.; Rath, L. M.; Bastia, D. K. and Khanda, C. M. (2006). Effect of planting geometry and nitrogen on yield, economics and nitrogen uptake of sweet corn (Zea mays). Indian J. Agron. 51(1): 43-45.

Khan, M. B.; Asif, M.; Aman, M. and Ahmad, T. (2002). Impact of intra-row spacing on growth and yield of some maize cultivars. J. Res. (Sci.), Bahauddin Zakariya Univ., Multan, Pakistan, 13(2): 135-38

Kumar, P.; Kumar, Y and Sarraf, A. (2004). Baby corn - A potential Crop. Intensive Agriculture. 3-9.

Kunjir, S. S.; Chavan, S. A.; Bhagat, S. B. and Zende, N. B. (2007). Effect of planting geometry, nitrogen levels and micronutrients on the growth and yield of sweet corn. Crop Prot. 2(3): 25-27.

Muthukumar, V. B.; Velayudham, K. and Thavaprakaash, N. (2005). Growth and yield of baby corn (Zea mays L.) as influenced by plant growth regulators and different time of nitrogen application. Res. J. Agric. Biol. Sci. 1(4):

303-307.

Nandal, D.P.S. and Agarwal, S.K. (1991). Response of winter maize to sowing dates, irrigation and nitrogen. Indian $J$. Agron. 36(2): 239-242.

Rahman, A.A.M.; Magboul, E.L. and Nour, A.E. (2001). Effect of sowing date and cultivar on the yield and yield components of maize in Northern Sudan. Seventh Eastern and Southern Africa Regional Maize Conference $11^{\text {th }}$ to $15^{\text {th }}$ February, pp. 295-298.

Rahmani, A.; Khorasani, S. K. and Kelat, M. N. (2010). Effect of sowing date and plant density on yield and yield its and some agronomic characteristics of baby corn cv. KSC403. Seed Plant Prod. J. 25-2(4): 449-463.

Ramachandrappa, B.K.; Nanjappa, H.V. and Shivakumar, H.K. (2004). Yield and quality of baby corn (Zea mays L.). as influenced by spacing and fertilizer levels. Acta- Agronomica- Hungarica. 52(3): 237-243.

Rathika, S. (2014). Influence of crop geometry, intercropping and topping practices on green cob yield and fodder quality of baby corn (Zea mays L.). Intern. J. Agil. Sci. 10(1): 182-185.

Sharifi, R. S.; Raei, Y. and Weisany, W. (2014). Study of physiological growth indices in maize (Zea mays L.) hybrids under different plant densities. Int. J. Biosci. 5(3): 100-109.

Song, C. Y.; Guo, K. and Liu, G. H. (2008). Effect of sowing date on yield and phytomass allocation of silage maize in Hunshandak Sandy Land. Chinese $J$. Eco-Agric. 16(4): 865-868.

Sukanya, T. S.; Nanjappa, H. V. and Ramachandrappa, B. K. (2000). Effect of Spacings on the Growth, Development and Yield of Baby corn 
(Zea mays L.) varieties. Karnataka J. Agric. Sci. 12: 10-14.

Thakur, D.R. and Sharma, V. (2000). Effect of planting geometry on babycorn yield in hybrid and composite cultivars of maize (Zea mays). Indian J. Agric. Sci. 70(4): 246-247

Thavaprakaash, N.; Velayudham, K. and Muthukumar, V.B. (2005). Effect of crop geometry, intercropping systems and integrated nutrient management practices on productivity of baby corn (Zea mays L.) based intercropping systems. Res. J. Agric. Biol. Sci. 1(4): 295-302.
Thavaprakaash, N. and Velayudham, K. (2009). Influence of crop geometry, intercropping systems and INM practices on productivity of baby corn (Zea mays L.) based intercropping system. Mysore J. Agric. Sci. 43(4): 686-695.

Verma, A. K.; Harika, A. S.; Singh, P. K.; Kaur, K. and Yadav, A. (2012). International Conference on Sustainable Agriculture for Food and Livelihood Security (701-702), Punjab Agricultural University, Ludhiana.

\section{How to cite this article:}

Lipika Talukdar, Pradip Chandra Bora, Khagen Kurmi and Sontara Kalita. 2020. Date of Sowing and Row Spacing for Improving Growth Attributes of Baby Corn. Int.J.Curr.Microbiol.App.Sci. 9(07): 1614-1621. doi: https://doi.org/10.20546/ijcmas.2020.907.186 